\title{
ASSESSing THE Role OF Historical Sites IN DAKAHLYA GOVERNORATE FOR ENHANCING Cultural TOURISM IN EgYPT
}

\section{By \\ Dr. Ahmed Adel Hammad}

Lecturer in the Tourism Studies Department, Faculty of Tourism and Hotels Mansoura University

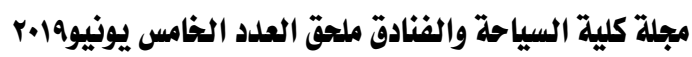

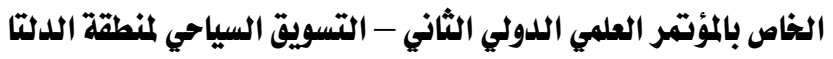


Assessing the Role of Historical Sites in Dakahlya Governorate for Enhancing Cultural Tourism in Egypt

\section{ASSESSING THE ROLE OF HistoricAl Sites IN \\ DAKAHLYA GOVERNORATE FOR ENHANCING Cultural TOURISM IN EgYPT}

\section{Abstract:}

\section{Dr. Ahmed Adel Hammad ${ }^{1}$}

Dakahlya governorate includes plenty of historical sites, which vary amongst archaeological places, relics of ancient Egyptian civilisations, religious sites of Coptic and Islamic worship, and sites of national importance. Nevertheless, these sites are not well exploited in favour of the Egyptian cultural tourism. This study aims at identifying and assessing historical sites in Dakahlya governorate, and shed light on the role they can play for enhancing cultural tourism in Egypt. The study depended on primary data through targeting questionnaire forms at a number of forty-five tourism experts in the Egyptian cities of Mansoura and Cairo; from October 2018 to February 2019. The questionnaire aimed at identifying experts' opinions on historical sites in Dakahlya governorate to assess their role in enhancing cultural tourism in Egypt. The study also depended on secondary data represented in Arabic and English books, periodicals, theses, dissertations and working papers related to the subject of study. The findings have revealed that the value of historical sites in Dakahlya governorate can help in enriching and enhancing cultural tourism in Dakahlya governorate and consequently in Egypt. However, many of these sites lack the necessary infrastructure and superstructure services that tourists need. Hence, the study's main recommendations focus on the necessity of implementing a successful development plan including the provision of infrastructure and superstructure services in the historical sites of Dakahlya governorate as well as raising the 
مجلة كلية السياحة والفنادق - ملحق العدد الخامس يونيو91r الخاص بالمؤتمر العلمي الثاني

local inhabitants' awareness of tourism, particularly cultural tourism.

Key words: Cultural Tourism - Dakahlya governorate - historical sites.

\section{تقييم دور المواقع التاريخية بمحافظة الدقهلية لتعزيز السياحة الثقافية في هصر}

| ال|خص:

تزخر محافظة الدقهلية بالعديد من المواقع التاريخية التي ممكن أن تسـاهم يِّ زيادة حركة السياحة الثقافية يِّ مصر، حيث تتنوع هذه المواقع بين المواقـع الأثريـة وأثار الحضـارات السـابقة والمواقِ الدينيـة المتمثلـة هِّ دور العبـادة القبطيـة والإسـلامية إضـافة إلى المواقع ذات الأهمية القومية، وبالرغم من ذلك فإن هذه المواقع ليس مستغلة يِ دعمم السياحة الثقافية ِِّ مصر.

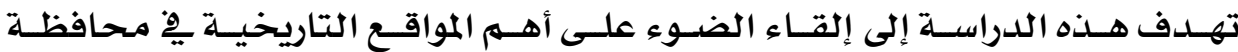

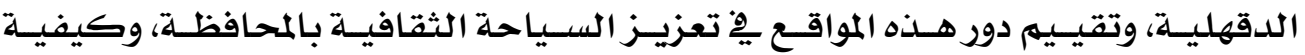
استغلال هذه المواقع ِِّ خدمة السياحة الثقافية يِّ مصر.

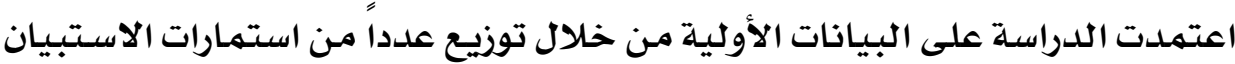

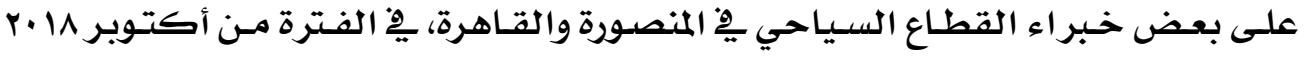
حتى فبر اير 19 بr، للتعرف على الآراء ووجهات النظر المختلفـة حول دور المواقع الأثريـة

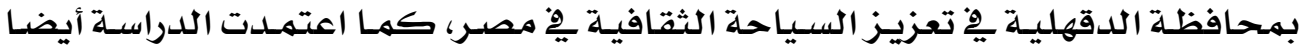

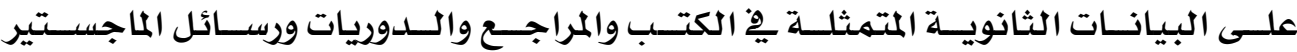
والدكتوراه المتعلقة بموضوع الدراسلة.

هذا، وقد أوضحت النتائج وجود العديد من المواقع الأثرية الهامة التي قد تسـاهم ِِ

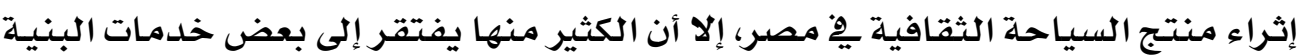
التحتيـة والفوقيـة الهامـة، ولذلك فهـذه الأمـاكن ليست مجهزة لاستقبال السـائحين، 
Assessing the Role of Historical Sites in Dakahlya Governorate for Enhancing Cultural Tourism in Egypt

ولذلك أوصت الدراسة بضـرورة تـوفير الخـدمات الأسـاسية مـن البنيـة الفوقيـة والتحتيـة

هِّ هذه المواقع، مـع ضرورة تكثيف الجهد المبذولة من قبل وزارة السياحة المصرية وهيئاتها

لنشـر الوعي السـياحي عن المواقـع الأثريـة بمحافظـة الدقهليـة سـواء بـين أبنـاء المجتهــع

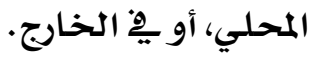

\section{Introduction:}

Tourism is one of the dynamic sectors that leads to the economic prosperity in many countries, and as a result of that it has been considered as an industry (Coccossis and Constantoglou, 2006; Frank and Medarić, 2018). It is a complicated phenomenon embracing a wide range of people travelling from one place to another for discovering new sites and having unique experiences, which can gratify their travel motivations (Fonseca et al., 2016; Fithriah et al., 2018). Tourism has developed into a significant international industry, particularly after the vertical and horizontal company amalgamations that created different scales of operation in many segments of market (Mousavi, 2016; Ghanem, 2017). The growth in international airlines, the cutting-edge technology and the burgeoning flexibility in tour arrangements have all helped in creating the present characteristics and structure of this industry (Lickorish and Jenkins, 1997). Tourism consists of several components and elements that work together in harmony for achieving tourists' satisfaction in the host community (Debes, 2010). It also creates a kind of social and cultural compatibility, which results from the exchange of cultures, traditions and customs amongst countries (Hammad, 2017). Furthermore, it is considered an essential activity in the economic mechanism structure and a key element in the development and modernisation of societies (Bunghez, 2016). Tourists travel commonly to destinations to see a precious artefact or to enjoy the great heritage of other countries (Hammad, 2017). As a result of the 


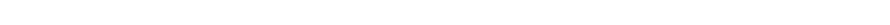

significant role that many historical sites in Egypt play in cultural tourism, the fondness for Egypt and its ancient civilisations was and still in increase. However, some of these sites are not wellexploited and require efforts to be prepared as cultural tourism destinations (Hammad, 2019).

\section{Problem of the Study:}

The study's core problem emerges from the fact that despite the great value of the different historical sites in Dakahlya governorate, they are not well exploited in favour of the Egyptian cultural tourism.

\section{Importance of the Study:}

The study's importance emerges from the advantages that historical sites in Dakahlya governorate have in favour of cultural tourism in Egypt.

\section{Objectives of the Study:}

The study aims at identifying the foremost historical sites in Dakahlya governorate, assessing them, coming up with solution to their pressing problems and shedding light on the role they can play in enhancing cultural tourism in Egypt.

\section{Literature Review: \\ 1. Gultural tourism:}

The known definition of tourism has two different categories; conceptual and technical. The conceptual definition of tourism deals with it as the temporary short-term movement of people to places outside their home and working environment for going on trips and enjoying different kinds of activities. The technical definition of tourism focuses on assessing and measuring its value as the act of people travelling to and staying in places outside their usual environment for a period of time not less than one day and not more than one consecutive year for leisure and cultural purposes excluding remunerated activities (Mousavi, 2016; Ghanem, 2017). Culture embraces arts, morals, customs, traditions, beliefs, attitudes, values and habits, which are 
Assessing the Role of Historical Sites in Dakahlya Governorate for Enhancing Cultural Tourism in Egypt

gained and shared by people and transferred from a generation to another. It also consists of patterns of behaviour that form the distinguished achievements of people. Therefore, culture can be considered as the collective programming of the mind that characterises members of one group or a category of people from another. It can be reflected in relics, antiquities and monuments of the past civilisations (Spencer-Oatey, 2012). When combining culture with tourism, cultural tourism is created. Thus, cultural tourism can be defined as visiting different forms of cultural sites of attraction e.g. monuments, museums and historical sites as well as the participation of tourists in a wide range of other related activities to the mentioned attractions at any time throughout the trip (Frank and Medarić, 2018).

\section{Gultural tourists:}

It was stated in a large body of literature that the majority of tourists are highly motivated to take part in cultural tourism (Becker, 2014). The typical cultural tourists are those people who accept and understand the way other people behave, and always look for new experiences at new destinations. They are characterised by their high educational level and their eagerness to spend more money on their trips (Gaffar et al., 2011; Kajzar, 2014). Therefore, cultural tourists have been categorised into five categories as indicated in the following points (Kajzar, 2014):

a-Purposeful cultural tourists i.e. tourists who regard cultural tourism as the main travel motivation and always look for a very deep experience.

b-Sightseeing cultural tourists i.e. tourists who have an important motivation for visiting a certain cultural site, but their experience is less deep.

c- Casual cultural tourists i.e. tourists whose cultural travel motivations are fragile and their cultural experience is little. 


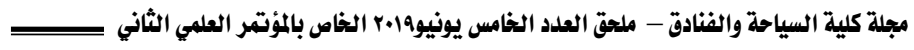

d-Incidental cultural tourists i.e. tourists who do not travel for cultural motivations, but take part in some cultural activities and have a little cultural background.

e- Serendipitous cultural tourists i.e. tourists who do not travel for specific cultural motivations, but have not a deep cultural tourism experience.

\section{Gultural tourism destinations:}

The tourism destination is known as an area that encompasses and offers products and services for tourists throughout their period of stay (Eraqi, 2007). It refers to a place or geographical unit e.g. a self-contained centre, an island, a village, a town, a city, a region, or a country where tourists plan to spend their holiday away from home (Breakey, 2005). Elements of tourist attraction are those basic components that should be included in the tourism destination for satisfying tourists and putting them at ease. They include for instance natural and cultural attractions as well as facilities and services offered in the host community e.g. places of accommodation, food and beverage establishments, shopping services, transport services and access routes to the destination (Ramadan and Hussein, 2017). There are other factors that affect on the competitiveness of the tourism destination e.g. its ability in increasing tourism expenditure, providing tourists with memorable experiences in a profitable way, enhancing the well-being of the host community and sustaining the destination for future generations (Mazanec, 2007). However, there are some historical sites that include monuments of a great value but lack the required facilities and service that constitute the lifeblood of the tourism industry (Vengesayi et al., 2009).

\section{Historical sites in Dakahlya Governorate:}

Dakahlya governorate is located in Lower Egypt, particularly in the north-east of the Egyptian Delta. When it appears on the map of Egypt, it takes the shape of an inverted 
Assessing the Role of Historical Sites in Dakahlya Governorate for Enhancing Cultural Tourism in Egypt

triangle surrounded by six Egyptian governorates, which are Damietta, Port Said, Sharkeya, Gharbeya, Kafr El-Shiekh and Kaliobeya. The Capital of Dakahlya governorate is Mansoura city whose name is connected with the Egyptian valour and triumphs (El-Dardiry and El-Ghonaimy, 2009; Ali, et al. 2017; Hammad, 2019). The name of Dakahlya was derived from an old Egyptian village named Dakahla, which was the base of Dakahlya region in the Arab invasion's time until the Mamlukes' era. Dakahlya governorate includes plenty of historical sites, which can help in creating a fertile environment for cultural tourism in Egypt. These sites vary amongst archaeological sites of ancient Egyptian civilisations, places of national significance and historical religious sites including Coptic and Islamic places of worship. Some of the archeological finds that were discovered in Dakahlya governorate have been sent to the Egyptian museum in Cairo so that they can be displayed for tourists to enjoy their splendour and glory. However, the original sites of these archaeological finds stand as a testament to the grandeur of the past Egyptian civilisations (Aly, 2011). Historical sites in Dakahlya governorate can be categorised as indicated in the following points:

\subsection{Sites of ancient Fgyptian civilisations:}

Sites of ancient Egyptian civilisations include for instance Tell Halbouny, Tell Bella, Tell El-Balamun, Tell El-Rub'a, Tell El-Ferkha, Tell El-Lugga, Tell Timei El-Amdid, Tell El-Khereba, Tell Al-Mekdam, Tell Meet Yaesh and Kom El-Hammamat (Wahby and Abdel Fattah, 2013). These sites are existed in the towns and villages of Dakahlya governorate and are noted for the discovery of relics and antiquities that date back to different Egyptian civilisations and eras e.g. the Pharoanic, the GaecoRoman and the Ptolemaic. Instances of the archaeological finds in these sites included funerary chambers, sarcophagi, human and animal burials, masks of pure gold, statues of kings and queens, pottery shards, coins, ruins of temples, fragments of red-brick, 
limestone buildings, stone tools, pots, shells and pottery fragments (Nour Eldin, 2010; Aly, 2011; Wahby and Abdel Fattah, 2013; Amin et al., 2017; Hammad et al., 2017).

\subsection{Historical Islamic sites:}

Dakahlya governorate is noted for its historical mosques, which stand as a real testament to the history of Islamic architecture in Egypt. These mosques feature Al-Mowafy Mosque in Mansoura city, which is the oldest mosque in Mansoura dating back to $998 \mathrm{AD}$ and was an important centre for Islamic studies, seminars and lectures (Khedr, 1992); Mohammed Ibn Abi Bakr Al-Sadeek Mosque in Aga town, which was constructed in 1950 AD for commemorating the Muslim martyr Mohammed Ibn Abi Bakr Al-Sadeek whose father was the first caliph of Muslims and whose grave was discovered in this village in 1950 AD (Khedr, 1992); El-Ghamry Mosque in Meet Ghamr town, which is noted for its minaret that dates back to the Mamlukes era (Ali et al., 2017), and Prince Hammad Mosque that dates back to 1616 AD, and which is a foremost hanging mosques from the Mamlukes era (Mohamed, 2012). Moreover, there are also other old mosques in Mansoura dating back to the eighteenth and nineteenth centuries and are distinguished by their unique Islamic architecture e.g. Sidi Hassan Al-Kenany Mosque, Sidi Al-Bahlol Mosque, Al-Dawlatly Mosque and Al-Emary Mosque (El-Sherbini, 2018).

\subsection{Historical Coptic sites:}

The two foremost historical Coptic sites in Dakahlya governorate include the Monastery of Saint Dimyana in Bilqas town and Saint George church in Aga town. The monastery of Saint Dimyana dates back to the fourth century and was built to commemorate the martyrdom of Saint Dimyana and forty virgins who were killed in the years of Christianity oppression in Egypt by the Romans (Gabra and Van Loon, 2012). On the other side, the historical Saint George Church, which commemorates the martyrdom of Saint George, consists of two buildings; one of 
Assessing the Role of Historical Sites in Dakahlya Governorate for Enhancing Cultural Tourism in Egypt

them dates back to 1800 AD (Mohamed, 2012). Moreover, there are also other old churches in Mansoura city dating back to the nineteenth and twentieth centuries and which are distinguished by their great architecture e.g. Saint Mary and Archangel Michael Coptic Orthodox Church that dates back to 1868 AD, Saint Elias Church that dates back to 1894 AD and Saint Nicolas Church that dates back to 1947 AD (El-Sherbini, 2018).

\subsection{Sites of national significance:}

Sites of national significance in Dakahlya governorate includes Mansoura National Museum; also known as Dar Ibn Louqman, which commemorates the triumph of Mansoura people over the crusade led by king Luis XI in 1250 AD (Mustafa, 2015); Al-Shenawy Palace in Mansoura city, which was built in 1928 $\mathrm{AD}$ in a distinguished Italian design for Mohamed Pasha AlShenawy who belonged to one of the aristocratic families in Mansoura city (Ali et al., 2015) and Alexander Palace, which is an old abandoned palace in Mansoura city dating back to the beginning of the twentieth century and which is distinguished by its unique architectural design, represented in the gothic style it has and the conical shape of its tower (Hammad, 2017; Hammad, 2019).

\section{Methodology:}

Considering the importance of assessing the role of historical sites in Dakahlya governorate for enhancing cultural tourism in Egypt, this study depended on utilising a mixed methodology including collection of primary and secondary data. The secondary sources that were discussed above and included books, theses, dissertations, periodicals, and working papers regarding the study's problem. The primary data consisted of a questionnaire form targeted specifically to a random sample of fifty tourism experts from the Egyptian Ministry of Tourism, the Federation of Tourism Chambers and the Egyptian Tourist Authority in both of Mansoura and Cairo. The number of 
retrieved valid questionnaire forms was forty-five. Although there was a difficulty in determining the actual size of the total community, it was important to provide broad indications to major directions for getting different views on historical sites in Dakahlya governorate and their role in enhancing cultural tourism in Egypt. Mansoura city was chosen as a place for carrying out the field study because it is the capital of Dakahlya governorate and the city where Dakahlya Local Tourist Authority is existed. Furthermore, Cairo was chosen to be another place for the field study because of the existence of the Egyptian Ministry of Tourism and the official tourism bodies in it. The questionnaire forms consisted of two sections. The first section aimed at obtaining the demographic data of respondents e.g. gender and years of work experience. The second section depended on posing seventeen-point Likert-type scale questions aimed at gathering more data and facts about historical sites in Dakahlya governorate. These data helped in evaluating the mentioned sites from the tourism perspective through identifying the challenges they face, identifying the availability of transforming them into cultural tourism destinations, identifying the appropriate development solutions they need in order to determine whether these sites can help in enhancing cultural tourism in Egypt or no. The relative weight, the arithmetic mean, the standard deviation, and Chi-Square " $\chi$ " were calculated in 5 points Likert-type Scale to show the difference amongst respondents' answers. The range of each level of agreement was calculated as follow:

$\circ$ Strongly disagree $=$ from 1 to 1.79

○ Disagree $=$ from 1.80 to 2.59

○ Do not know $=$ from 2.60 to 3.39

○ Agree $=$ from 3.40 to 4.19

○ Strongly agree $=$ from 4.20 to 5.00

A pre-test was carried out to test wording, layout and completion time. The internal coherence of statements was determined by 
_ Assessing the Role of Historical Sites in Dakahlya Governorate for Enhancing Cultural Tourism in Egypt

calculating correlation coefficients between each statement's degree and the questionnaire's total degree. The correlation coefficient ranged between 0.63 and 0.87 , which means that statements are valid for their purpose; at a significance level of 0.01 . The questionnaire's reliability was tested via Cronbach's alpha, which valued at 0.94 representing a high percentage of reliability. After the forms had been adjusted, they were carried out in five months; from October, 2018 to February, 2019. The gathered data were analysed by using the SPSS programme (Statistical Package for the Social sciences); version 25.

\section{Results and Discussion:}

\section{Section One:}

\section{Question No. 1 Gender:}

The purpose of this question is to know the distribution percentage of the respondents' gender. Table (1) shows that males are more than females as $73.33 \%$ of all respondents were males in comparison with only $26.67 \%$ females.

\section{Table 1: Respondents' Gender}

\begin{tabular}{|c|c|c|}
\hline Gender & Number & Percentage \\
\hline Male & 33 & 73.33 \\
\hline Female & 12 & 26.67 \\
\hline Total & 45 & 100 \\
\hline
\end{tabular}

\section{Question No. 2 Years of Work Bxperience:}

The purpose of this question is to know the distribution percentage of respondents' years of work experience. Table (2) shows that the majority of the respondents' years of work experience are from more than 10 years to 15 years; representing $48.89 \%$. On the other side, respondents' years of work experience that is more than 5 to 10 years represents $15.56 \%$, whereas $35.56 \%$ of them have a work experience for more than 15 years.

Table 2: Respondents' Work Experience

\begin{tabular}{|l|c|c|}
\hline Years of Experience & Number & Percentage \\
\hline Less than 5 years & 0 & 00.00 \\
\hline
\end{tabular}




\begin{tabular}{|c|c|c|}
\hline More than 5 to 10 years & 7 & 15.56 \\
\hline More than 10 to 15 years & 22 & 48.89 \\
\hline More than 15 years & 16 & 35.56 \\
\hline Total & 45 & 100 \\
\hline
\end{tabular}

\section{Section Two:}

Table 3: The Capability of Historical Sites in Dakahlya Governorate in Enhancing Cultural Tourism in Egypt

\begin{tabular}{|c|c|c|c|c|c|c|c|}
\hline $\begin{array}{c}\text { No } \\
\cdot\end{array}$ & Statement & $\chi^{2}$ & Sig. & $\underset{\mathbf{n}}{\mathrm{Mea}}$ & SD & $\begin{array}{c}\text { Relative } \\
\text { Weight } \\
(\%)\end{array}$ & $\begin{array}{c}\text { Degree of } \\
\text { Agreeme } \\
\text { nt }\end{array}$ \\
\hline & $\begin{array}{l}\text { Dakahlya governorate } \\
\text { includes plenty of } \\
\text { historical sites that can } \\
\text { help in enhancing } \\
\text { cultural tourism in } \\
\text { Egypt }\end{array}$ & $\begin{array}{c}19.6 \\
0 \\
\end{array}$ & $\begin{array}{c}0.00 \\
1\end{array}$ & 4.20 & 0.59 & 84.00 & $\begin{array}{c}\text { Strongly } \\
\text { Agree }\end{array}$ \\
\hline & $\begin{array}{l}\text { Dakahlya governorate } \\
\text { includes a sufficient } \\
\text { number of Pharaonic } \\
\text { sites }\end{array}$ & $\begin{array}{c}10.5 \\
3\end{array}$ & $\begin{array}{c}0.00 \\
5\end{array}$ & 4.38 & 0.68 & 87.56 & $\begin{array}{l}\text { Strongly } \\
\text { Agree }\end{array}$ \\
\hline & $\begin{array}{l}\text { Dakahlya governorate } \\
\text { includes a sufficient } \\
\text { number of } \text { Graeco- } \\
\text { Roman sites }\end{array}$ & $\begin{array}{c}21.5 \\
6\end{array}$ & $\begin{array}{c}0.00 \\
1\end{array}$ & 3.82 & 1.09 & 76.44 & Agree \\
\hline & $\begin{array}{l}\text { Dakahlya governorate } \\
\text { includes a sufficient } \\
\text { number of historical } \\
\text { Islamic sites }\end{array}$ & & $\begin{array}{c}0.00 \\
1\end{array}$ & 4.47 & 0.63 & 89.33 & $\begin{array}{c}\text { Strongly } \\
\text { Agree }\end{array}$ \\
\hline & $\begin{array}{l}\text { Dakahlya governorate } \\
\text { includes a sufficient } \\
\text { number of } \\
\text { Coptic sites }\end{array}$ & 21.78 & $\begin{array}{c}0.00 \\
1\end{array}$ & 3.47 & 1.08 & 69.33 & Agree \\
\hline
\end{tabular}


_ Assessing the Role of Historical Sites in Dakahlya Governorate

for Enhancing Cultural Tourism in Egypt

Table 3: To be Continued

\begin{tabular}{|c|c|c|c|c|c|c|}
\hline Statement & $\chi^{2}$ & Sig. & $\begin{array}{c}\text { Mea } \\
\text { n }\end{array}$ & SD & $\begin{array}{c}\text { Relative } \\
\text { Weight } \\
(\%)\end{array}$ & $\begin{array}{l}\text { Degree of } \\
\text { Agreeme } \\
\text { nt }\end{array}$ \\
\hline $\begin{array}{l}\text { Dakahlya governorate } \\
\text { includes a sufficient } \\
6 \text { number of Jewish sites }\end{array}$ & $\begin{array}{c}52.9 \\
3\end{array}$ & $\begin{array}{c}0.00 \\
1\end{array}$ & 1.22 & 0.56 & 24.44 & $\begin{array}{l}\text { Strongly } \\
\text { Disagree }\end{array}$ \\
\hline $\begin{array}{l}\text { Dakahlya governorate } \\
\text { includes a sufficient } \\
\text { number of national } \\
\text { significance sites such } \\
7 \text { as museums }\end{array}$ & $\begin{array}{c}11.2 \\
7\end{array}$ & $\begin{array}{c}0.01 \\
0\end{array}$ & 2.13 & 0.87 & 42.67 & Disagree \\
\hline $\begin{array}{l}\text { Historical sites in } \\
\text { Dakahlya governorate } \\
\text { are supplied with } \\
\text { sufficient facilities and } \\
\text { services that tourists } \\
8 \text { need }\end{array}$ & & $\begin{array}{c}0.00 \\
6\end{array}$ & 2.51 & 0.94 & 50.22 & Disagree \\
\hline $\begin{array}{l}\text { The local population } \\
\text { of Dakahlya has a } \\
\text { heightened awareness } \\
9 \text { of tourism }\end{array}$ & $\begin{array}{c}11.2 \\
7\end{array}$ & $\begin{array}{c}0.01 \\
0\end{array}$ & 2.13 & 0.87 & 42.67 & Disagree \\
\hline $\begin{array}{l}\text { Tourist trips are } \\
\text { organised regularly to } \\
\text { the historical sites in } \\
10 \text { Dakahlya }\end{array}$ & $\begin{array}{c}12.5 \\
1\end{array}$ & $\begin{array}{c}0.00 \\
6\end{array}$ & 2.51 & 0.94 & 50.22 & Disagree \\
\hline $\begin{array}{l}\text { There is a public body } \\
\text { responsible for } \\
\text { gathering data about } \\
\text { historical sites in } \\
\text { Dakahlya governorate } \\
11 \text { and promoting them }\end{array}$ & $\begin{array}{c}29.2 \\
0\end{array}$ & $\begin{array}{c}0.00 \\
1\end{array}$ & 4.07 & 0.54 & 81.33 & Agree \\
\hline
\end{tabular}




\begin{tabular}{|c|c|c|c|c|c|c|}
\hline $\begin{array}{l}\text { There are promotional } \\
\text { campaigns for } \\
\text { enhancing cultural } \\
\text { tourism in Dakahlya } \\
12 \text { Governorate }\end{array}$ & $\begin{array}{c}25.2 \\
0\end{array}$ & $\begin{array}{c}0.00 \\
1\end{array}$ & 4.60 & 0.62 & 92.00 & $\begin{array}{c}\text { Strongly } \\
\text { Agree }\end{array}$ \\
\hline $\begin{array}{lr}\text { Historical sites in } \\
\text { Dakahlya governorate } \\
\text { can }\end{array}$ & $\begin{array}{c}22.9 \\
3\end{array}$ & $\begin{array}{c}0.00 \\
1\end{array}$ & 4.58 & 0.62 & 91.56 & $\begin{array}{c}\text { Strongly } \\
\text { Agree }\end{array}$ \\
\hline $\begin{array}{l}\text { Historical sites in } \\
\text { Dakahlya Governorate } \\
\text { can attract domestic } \\
14 \text { tourists }\end{array}$ & $\begin{array}{c}29.2 \\
0\end{array}$ & $\begin{array}{c}0.00 \\
1\end{array}$ & 4.07 & 0.54 & 81.33 & Agree \\
\hline
\end{tabular}

\section{Table 3: To be Continued}

\begin{tabular}{|c|c|c|c|c|c|c|c|}
\hline No & Statement & $\chi^{2}$ & Sig. & $\begin{array}{c}\text { Mea } \\
\text { n }\end{array}$ & SD & $\begin{array}{c}\text { Relative } \\
\text { Weight } \\
(\%)\end{array}$ & $\begin{array}{l}\text { Degree of } \\
\text { Agreeme } \\
\text { nt }\end{array}$ \\
\hline & $\begin{array}{l}\text { Dakahlya governorate } \\
\text { has a fertile } \\
\text { environment } \\
\text { tourism investment }\end{array}$ & $\begin{array}{c}40.4 \\
2\end{array}$ & $\begin{array}{c}0.00 \\
1\end{array}$ & 4.49 & 0.79 & 89.78 & $\begin{array}{c}\text { Strongly } \\
\text { Agree }\end{array}$ \\
\hline & $\begin{array}{l}\text { There is a plan for } \\
\text { supporting Dakahlya } \\
\text { governorate to be } \\
\text { incorporated into the } \\
\text { Egyptian tourism map }\end{array}$ & 8.40 & $\begin{array}{c}0.01 \\
5\end{array}$ & 4.33 & 0.71 & 86.67 & $\begin{array}{c}\text { Strongly } \\
\text { Agree }\end{array}$ \\
\hline & $\begin{array}{l}\text { The optimisation of } \\
\text { historical sites in } \\
\text { Dakahlya governorate } \\
\text { can help in enhancing } \\
\text { cultural tourism in } \\
\text { Egypt }\end{array}$ & $\begin{array}{c}36.1 \\
3\end{array}$ & $\begin{array}{c}0.00 \\
1\end{array}$ & 3.98 & 0.50 & 79.56 & Agree \\
\hline \multicolumn{4}{|c|}{ Average } & 3.58 & & & Agree \\
\hline
\end{tabular}


Assessing the Role of Historical Sites in Dakahlya Governorate for Enhancing Cultural Tourism in Egypt

The previous table (3) revealed some important facts concerning the capability of Dakahlya governorate's historical sites in enhancing cultural tourism in Egypt, as indicated in the following points:

- Concerning "Dakahlya governorate includes plenty of historical sites that can help in enhancing cultural tourism in Egypt", respondents' answers represented 19.60 for the Chi-Square's value at a significant level of 0.001 , which means that there are statistically significant differences amongst respondents. The total answers of that statement were 'strongly agree' representing an arithmetic mean of 4.20 and a relative weight of $84 \%$.

- Concerning "Dakahlya governorate includes a sufficient number of Pharaonic sites", respondents' answers represented 10.53 for the Chi-Square's value at a significant level of 0.005 , which means that there are statistically significant differences amongst respondents. The total answers of that statement were 'strongly agree' representing an arithmetic mean of 4.38 and a relative weight of $87.56 \%$.

- Concerning "Dakahlya Governorate includes a sufficient number of Graeco-Roman sites", respondents' answers represented 21.56 for the Chi-Square's value at a significant level of 0.001 , which means that there are statistically significant differences amongst respondents. The total answers of that statement were 'agree' representing an arithmetic mean of 3.82 and a relative weight of $76.44 \%$.

- Concerning "Dakahlya governorate includes a sufficient number of historical Islamic sites", respondents' answers represented 15.60 for the Chi-Square's value at a significant level of 0.001 , which means that there are statistically significant differences amongst respondents. The total answers of that statement were 'strongly agree' representing an arithmetic mean of 4.47 and a relative weight of $89.33 \%$. 
- Concerning "Dakahlya governorate includes a sufficient number of historical Coptic sites", respondents' answers represented 21.78 for the Chi-Square's value at a significant level of 0.001 , which means that there are statistically significant differences amongst respondents. The total answers of that statement were 'agree' representing an arithmetic mean of 3.47 and a relative weight of $69.33 \%$.

- Concerning "Dakahlya governorate includes a sufficient number of Jewish sites", respondents' answers represented 52.93 for the Chi-Square's value at a significant level of 0.001, which means that there are statistically significant differences amongst respondents. The total answers of that statement were 'strongly disagree' representing an arithmetic mean of 1.22 and a relative weight of $24.44 \%$.

- Concerning "Dakahlya governorate includes a sufficient number of national significance sites such as museums", respondents' answers represented 11.27 for the Chi-Square's value at a significant level of 0.010 , which means that there are statistically significant differences amongst respondents. The total answers of that statement were 'disagree' representing an arithmetic mean of 2.13 and a relative weight of $42.67 \%$.

- Concerning "Historical sites in Dakahlya governorate are supplied with sufficient facilities and services that tourists need", respondents' answers represented 12.51 for the Chi-Square's value, at a significant level of 0.006 , which means that there are statistically significant differences amongst respondents. The total answers of that statement were 'disagree' representing an arithmetic mean of 2.51 and a relative weight of $50.22 \%$.

- Concerning "The local population of Dakahlya has a heightened awareness of tourism", respondents' answers represented 11.27 for the Chi-Square's value at a significant level of 0.010 , which means that there are statistically significant differences amongst respondents. The total answers of that 
Assessing the Role of Historical Sites in Dakahlya Governorate for Enhancing Cultural Tourism in Egypt

statement were 'disagree' representing an arithmetic mean of 2.13 and a relative weight of $42.67 \%$.

- Concerning "Tourist trips are organised regularly to the historical sites of Dakahlya", respondents' answers represented 12.51 for the Chi-Square's value at a significant level of 0.006 , which means that there are statistically significant differences amongst respondents. The total answers of that statement were 'disagree' representing an arithmetic mean of 2.51 and a relative weight of $50.22 \%$.

- Concerning "There is a public body responsible for gathering data about historical sites in Dakahlya governorate and promoting them", respondents' answers represented 29.20 for the ChiSquare's value at a significant level of 0.001 , which means that there are statistically significant differences amongst respondents. The total answers of that statement were 'agree' representing an arithmetic mean of 4.07 and a relative weight of $81.33 \%$.

- Concerning "There are promotional campaigns for enhancing cultural tourism in Dakahlya governorate", respondents' answers represented 25.20 for the Chi-Square's value at a significant level of 0.001 , which means that there are statistically significant differences amongst respondents. The total answers of that statement were 'strongly agree' representing an arithmetic mean of 4.60 and a relative weight of $92.00 \%$.

- Concerning "Historical sites in Dakahlya governorate can attract international tourists", respondents' answers represented 22.93 for the Chi-Square's value at a significant level of 0.001 , which means that there are statistically significant differences amongst respondents. The total answers of that statement were 'strongly agree' representing an arithmetic mean of 4.58 and a relative weight of $91.56 \%$.

- Concerning "Historical sites in Dakahlya governorate can attract domestic tourists", respondents' answers represented 29.20 for the Chi-Square's value at a significant level of 0.001, which 


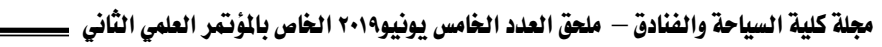

means that there are statistically significant differences amongst respondents. The total answers of that statement were 'agree' representing an arithmetic mean of 4.07 and a relative weight of $81.33 \%$.

- Concerning "Dakahlya governorate has a fertile environment for tourism investment", respondents' answers represented 40.42 for the Chi-Square's value at a significant level of 0.001 , which means that there are statistically significant differences amongst respondents. The total answers of that statement were 'strongly agree' representing an arithmetic mean of 4.49 and a relative weight of $89.78 \%$.

- Concerning "There is a plan for supporting Dakahlya governorate to be incorporated into the Egyptian tourism map", respondents' answers represented 8.40 for the Chi-Square's value at a significant level of 0.015 , which means that there are statistically significant differences amongst respondents. The total answers of that statement were 'strongly agree' representing an arithmetic mean of 4.33 and a relative weight of $86.67 \%$.

- Concerning "The optimisation of historical sites in Dakahlya governorate can help in enhancing cultural tourism in Egypt", respondents' answers represented 36.13 for the Chi-Square's value at a significant level of 0.001 , which means that there are statistically significant differences amongst respondents. The total answers of that statement were 'agree' representing an arithmetic mean of 3.98 and a relative weight of $79.56 \%$.

The general answers of respondents were at the level of "agree" for all questionnaire's statements representing a general arithmetic mean of 3.58, which approves the capability of historical sites in Dakahlya governorate in enhancing cultural tourism in Egypt.

\section{Conclusion:}

This study has been presented as an investigation into assessing the role of historical sites in Dakahlya governorate for 
Assessing the Role of Historical Sites in Dakahlya Governorate for Enhancing Cultural Tourism in Egypt

enhancing cultural tourism in Egypt. It was applied on a random sample of forty-five tourism experts from different tourism bodies in the cities of Mansoura and Cairo. The findings revealed that Dakahlya governorate has many factors that can help in enriching cultural tourism in Egypt. These factors are represented in its different historical sites that date back to different civilisations and eras e.g. the Pharoanic, the Graeco-Roman and the Ptolemaic. Furthermore, there is an existence of Coptic and Islamic historical sites of worship represented in historical churches, monasteries and mosques, as well as sites of national significance represented in a limited number of palaces and old structures. However, Jewish sites are not currently existed in Dakahlya as they were in the past. The cultural value of these sites can create a fertile environment for attracting cultural tourists and encouraging the tourism investment in Mansoura city; the capital of Dakahlya. However, there are some problems and challenges facing many of these sites. These obstacles are presented in the inadequate superstructure e.g. road networks and accommodation in many areas, specially towns and villages of Dakahlya governorate where archaeological sites that are exited. Thus, these sites have become confined to the visits of archaeological missions and excavators who carry out excavation works and do field studies about archaeological discoveries. Nevertheless, these sites are sometimes visited by the organised daytrips of school pupils and university students. Another problem is that the local inhabitants in many towns and villages of Dakahlya governorate have not the enough awareness of tourism and cannot easily accept the existence of tourists amongst them. As soon as essential facilities and services are provided and the local inhabitants' awareness of tourism is raised, these sites can be prepared for receiving tourists and consequently they will result in enhancing the cultural tourism in Egypt. At present, there are some executed efforts by Dakahlya governorate, the Egyptian Ministry of Tourism, the 
Egyptian ministry of Antiquities and the Local Tourist Authority of Dakahlya for promoting these historical sites and incorporating Dakahlya governorate into the Egyptian tourist map.

\section{Recommendations targeted at the Fgyptian Ministry of Tourism and its bodies:}

- Strengthening co-operation between the Egyptian Ministry of Tourism and the Egyptian Ministry of Antiquities for preserving and revitalising all archaeological sites of Dakahlya governorate as well as maintaining and protecting its sites of national significance such as palaces for transferring them into museums.

- Strengthening co-operation amongst the Egyptian Ministry of Tourism, the Egyptian Ministry of Environment, the Egyptian Ministry of Housing Utilities and Urban Communities, and the Egyptian Ministry of Local Development for providing the basic infrastructure such as establishing a road network linking all sites of Dakahlya governorate with Mansoura city.

- Carrying out periodical follow-up campaigns for the historical sites in Dakahlya governorate for monitoring and recording any negative observations, so that the proper decision can be taken.

- Carrying out local and international campaigns for raising awareness of historical sites in Dakahlya governorate.

- Issuing printed and electronic brochures as well as annual bulletins in different languages about historical sites in Dakahlya governorate and addressing them to travel agencies in Egypt and abroad.

- Promoting the archeological sites of Dakahlya governorate by using the different forms of internet media, including social media.

- Providing different tourism programmes with different prices in travel agencies for encouraging cultural tourists to visit Dakahlya governorate as a cultural tourism destination.

${ }^{1}$ Lecturer in the Tourism Studies Department, Faculty of Tourism and Hotels - Mansoura University 
Assessing the Role of Historical Sites in Dakahlya Governorate for Enhancing Cultural Tourism in Egypt

\section{References:}

\section{English References:}

- Ali, M., Ali, M., Darwish, S., Saker, U., Ciliberto, E., Greco, E. and Viscuzo, E. (2015): Investigation and Conservation of ElShenawy Palace Photographic Collection in Mansoura Egypt, Mediterranean Archaeology and Archaeometry, 15(3), pp. 165185.

- Amin, W. S., El azab, T. K., Hizah, D. S. M., and Hammad, A. A., (2017): Dark Tourism as a New Trend in the Egyptian Tourism Industry: Challenges and Opportunities, Minia Journal of Tourism and Hospitality Research, 1(2), pp. 20-52.

- Becker, P. (2014): The Different Types of Tourists and their Motives when Visiting Alaska during the Iditarod, Unpublished Master Thesis, Finnmark Faculty, Arctic University of Norway, Norway.

- Bunghez, C. L. (2016): The Importance of Tourism to a Destination Economy, Journal of Eastern Europe Research in Business and Economics, Vol. 2016, ID 143495, DOI 10.511, pp. $1-9$

- Breakey, N. M. (2005): Tourism Destination Development beyond Butler, Unpublished PhD Dissertation, the University of Queensland, Australia.

- Coccossis, H. and Constantoglou, M. E. (2006): The Use of Typologies in Tourism Planning: Problems and Conflicts, 4th Congress off the European Regional Science Association, Enlargement Southern Europe and the Mediterranean, Department of Planning and Regional Development, University of Thessaly, Greece, pp.1-22.

- El-Dardiry, D. and El- Ghonaimy, E. (2009): Impact of Conflict between Regional Planning Policy and Cities Strategies upon Cities Urban Situation, Case Study: Mansoura City Egypt, Journal of Engineering Sciences, Assiut University, 37(6), pp. 1551-1580. 
- Eraqi, M. I., (2007): Egypt as a Macro-tourist Destination: Tourism Services Quality and Positioning, Int. J. Services and Operations management, 3(3), pp. 1-19.

- Fithriah, F.F.; Susilowati, M. H. D. and Rizqihandari, N. (2018): Tourist Movement patterns between Tourist Sites in DKH Jakarta, IOP. Con. Ser.: Earth Environ. Sci., 145 012143, pp. 110.

- Fonseca, A. P., Seabra, C. and Silva, C., (2016): Dark Tourism: Concepts, Typologies and Site, Journal of Tourism Research and Hospitality, S2-002, USA, pp.1-6.

- Frank, T. O. and Medarić, Z. (2018): Cultural Tourism from an Academic Perspective, Academia Touristica, Year 11, No. 2, pp.101-110.

- Gabra, G. and Van Loon, G. (2012): The Churches of Egypt: from the Journey of the Holy Family to the Present day, the American University in cairo Press, Cairo, Egypt.

- Gaffar, V., HP., P. W. and Setiyorini, D. (2011): Comparative Study of Tourist Characteristics on Cultural Heritage Tourism Sites: Survey on Tourist in Indonesia and Thailand Heritage Sites, Journal of Tourism Hospitality and Culinary Arts, 3(3), pp. 53-.

- Ghanem, J. (2017): Conceptualizing the Tourist, A Critical Review of UNWTO Definition, Unpublished Master Thesis, Faculty of Tourism, University of Girona, Girona, Catalonia, Spain.

- Hammad, A. A. (2019): Dark Tourism in Egypt: A Trip to the Exciting Past, 1st Ed., Rawabt for Publishing and Information Technology, Cairo, Egypt.

- Kajzar, P. (2014): Cultural Tourism and World Heritage, International Colloquium on Regional Science, Hustopeče, Czech Republic, pp. 18-20. 
Assessing the Role of Historical Sites in Dakahlya Governorate for Enhancing Cultural Tourism in Egypt

- Lickorish, L. J. and Jenkins, C. L. (1997): An Introduction to Tourism, 1st Ed., Butterworth-Heinemann, Reed Educational and Professional Publishing Ltd., Oxford, UK.

- Mazanec, J. A., Wober, R. and Zins, A.H. (2007): Tourism Destination Comptitiveness: From Definition to Explanation, Journal of Travel Resercah, 46, 10.1177110047287507302389, pp. 86-95.

- Mousavi, S. S., Doratli, N., Mousavi, S. N. and Moradiahari, F. (2016): Defining Cultural Tourism, International Conference of Civil Architecture and Sustainable Development, London, UK, Available on: https://doi.org/10.15242/IICBE.DIR1216411, Last Access: 19/01/2019, 10:15 PM.

- Spencer-Oatey, H. (2012): What is Culture? A Compilation of Questions. GlobalPAD Core Concepts, Available on:

- http://www.warwick.ac.uk/globalpadintercultural, Last Access: (16/01/2019), 02:00 AM.

- Ramadan, A. and Hussein, A. (2017): Evaluating the Egyptian Tourism Product Image in the Tour Operators' Brochure, Minia Journal of Tourism and Hospitality research, 1(2), Minia, Egypt, pp.53-75.

- Vengesayi, S., Mavondo, F. T. and Reisinger, Y. (2009): Tourism Destination Attractiveness: Attractions, Facilities and People as Predictors, Tourism Analysis, 14(5), pp. 621-636.

- Wahby. A. and Abdel Fattak, K. (2013): Some Little Known Archaeological Sites in Dakahlya Governorate, Delta Survey Workshop, British Council, Cairo, Egypt, pp. 1-12.

\section{المراجع الهربية:}

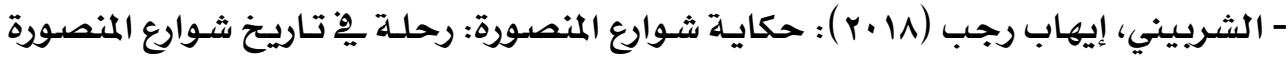
وأحيائها، مطبعة الإيمان، المنصورة، ج.م.ع. 
- حمـاد، أحمد عادل (10 ·r) : تأثير الأزمـة العالميـة على أنثطة شـركات السياحلة: دراسـة تطبيقية على مصر، المؤسسة المصرية للتسويق والتوزيع، القاهرة، ج.م.ع.

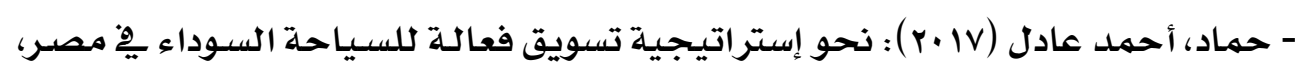
رسـالة دكتوراه، قسـم الدراسـات السيـاحية، كليـة السيـاحة والفنـادق، جـامعـة المنصسورة، ج.?.?. - حماد، أحمد عادل وعلي، كريهم أحمد عبد الفتاح وعبد الله، وليد سيد أمـين (r · ) : نحـو تنهميـة سـياحية مسـتدامـة لمنطقـة تـل الفرخـة بهـحافظــة الدقهليـة، مـجلـة كليـة

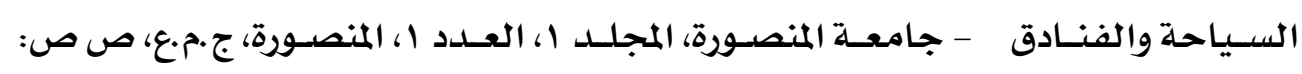
. rrr- r..

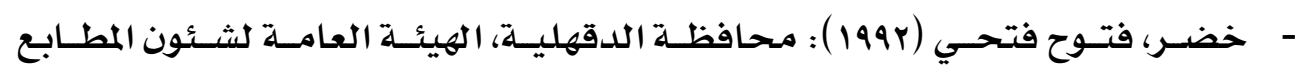

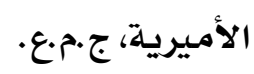

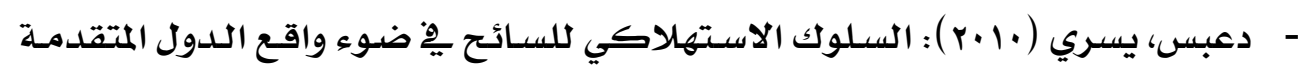
والدول الناميـة: دراسـة يِ الأنثروبولوجيـا الاقتصـاديـة، الطبعـة الأولى، البيطـاش سـنتر للنشر والتوزيع، الإسكندرية، ج.م.ع.

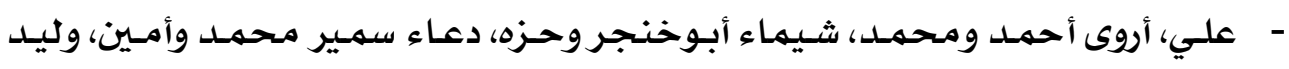

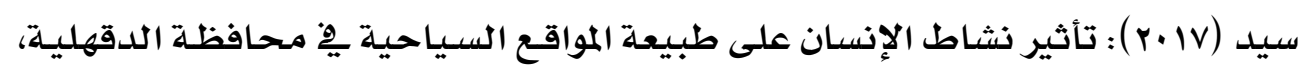

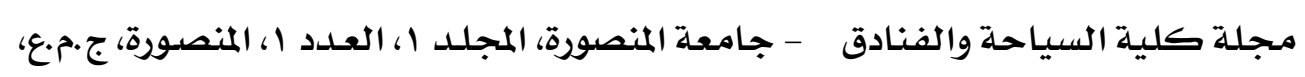
ص صט: rov- rus

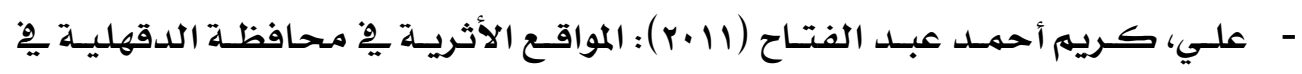
العصر الفرعوني، رسالة ماجستير غير منششورة، قسم الإرشاد السـياحي، كليـة السياحة والفنادق، جامعة المنصورة، ج.م.ع.

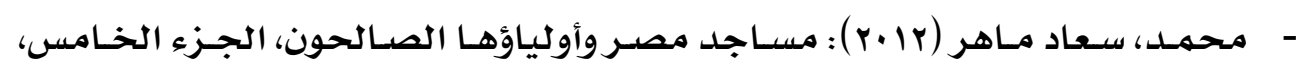
المجلس الأعلى للشئون الإسـلامية، دار الكتب المصريـة، القاهرة، ج.م.ع. 
Assessing the Role of Historical Sites in Dakahlya Governorate

= for Enhancing Cultural Tourism in Egypt

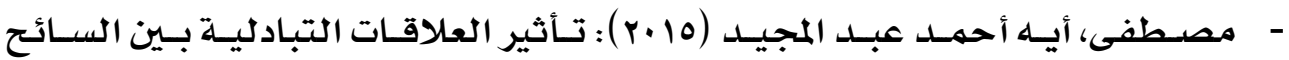
والمجتهــع المضـيف على الحركـة السـياحية لإقلـيهم شـرق الــلتا، رسـالة ماجسـتير غـير منشورة، قسهم الدراسـات السياحة، كلية السياحة والفنادق، جامعة المنصورة، ج.م.ع.

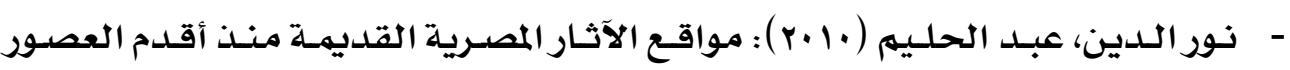
وحتى نهايـة عصر الأسـرات المصريـة القديمة، الجزء الأول: مواقع مصر السـفلى، الطبعـة الثامنـة، المؤسسة المصرية للتوزيـع والتسويق، القاهرة، ج.م.ع. 